\title{
Revisiting the absolute calibration of the Greenland ice-core age-scales*
}

\author{
L. C. Skinner \\ Godwin Laboratory for Palaeoclimate Research, Department of Earth Sciences, University of Cambridge, Downing Street, \\ Cambridge, CB2 3EQ, UK \\ *Invited contribution by L. Skinner, one of the EGU Outstanding Young Scientist Award winners 2006.
}

Received: 21 May 2008 - Published in Clim. Past Discuss.: 25 June 2008

Revised: 10 September 2008 - Accepted: 17 October 2008 - Published: 24 November 2008

\begin{abstract}
Recently, an absolute "calibration" was proposed for the GRIP and GISP2 Greenland ice-core time scales (Shackleton et al., 2004). This calibration attempted to reconcile the stratigraphic integration of ice-core, marine and speleothem archives with the absolute age constraints that marine and speleothem records incorporate. Here we revisit this calibration in light of the new layer-counted chronology of the NGRIP ice-core (GICC05). The GICC05 age-scale differs from the proposed absolute calibration by up to 1200 years late in the last glaciation, with implications both for radiocarbon cycling and the inferred timing of North Atlantic climate events relative to radiometrically dated archives (e.g. relative sea-level). By aligning the stratigraphy of Iberian Margin marine cores with that of the Greenland ice-cores, it can be shown that either: 1) the radiocarbon content of mid-latitude Atlantic surface-waters was extremely depleted (resulting in average surface reservoir ages up to 1700 years prior to $\sim 22 \mathrm{kaBP}$ ); or 2) the GICC05 age-scale includes too few years (is up to 1200 years too young). It is shown here that both of these possibilities are probably correct to some degree. Based on the assumed accuracy of coral and speleothem U-Th ages, Northeast Atlantic surface reservoir ages should be revised upward by $\sim 350$ years, while the NGRIP age-scale appears to be "missing" time. These findings illustrate the utility of integrated stratigraphy as a test for our chronologies, which are rarely truly "absolute". This is an important point, since probably the worst error that we can make is to entrench and generalise a precise stratigraphical relationship on the basis of erroneous absolute age assignations.
\end{abstract}

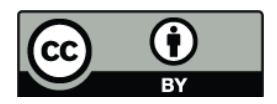

Correspondence to: L. C. Skinner (luke00@esc.cam.ac.uk)

\section{Introduction}

All palaeoenvironmental inference hinges on chronostratigraphy. Without a way to accurately link and order our observations spatially and temporally, they remain at best of ambiguous, and at worst of dubious, significance. Nevertheless, a given chronostratigraphy is best viewed as an hypothesis. Much like any proxy, a chronostratigraphy must be employed in a manner that explicitly allows it to be tested. The Greenland and Antarctic ice-core stratigraphies, together with North Atlantic marine archives, low-latitude speleothem and coral records, and the radiometric dates that these latter archives contain, comprise an integrated chronostratigraphic system that is eminently amenable to consistency testing. The integration of these "chronostratigraphic elements" results in a system that remains underdetermined, in that it's chronology cannot be resolved unequivocally. However, this is only true to the extent that proposed stratigraphic links and absolute ages can be questioned, and that radiometric ages are subject to uncertain "calibrations" (i.e. we cannot account for the movement of all radio-isotopes in the system). Nevertheless, this integrated chronostratigraphic system remains explicit, in the sense that any proposed uncertainties or difficulties in the correlations or chronologies carry clear implications that can be explicitly evaluated. Thus if the Greenland, Cariaco, Iberian Margin, Hulu, Dongge and Boutavera records all contain the same "event stratigraphy", then their chronologies must be consistent; both with each other, and with existing radiometric calibrations (such as paired radiocarbon-uranium-series dated corals). Should this not be the case, one can (and must) draw clear conclusions: either regarding absolute age-determinations, radiometric calibrations and/or reservoir effects, or regarding the initial stratigraphic correlations.

Published by Copernicus Publications on behalf of the European Geosciences Union. 
Absolute calibration of Greenland revisited

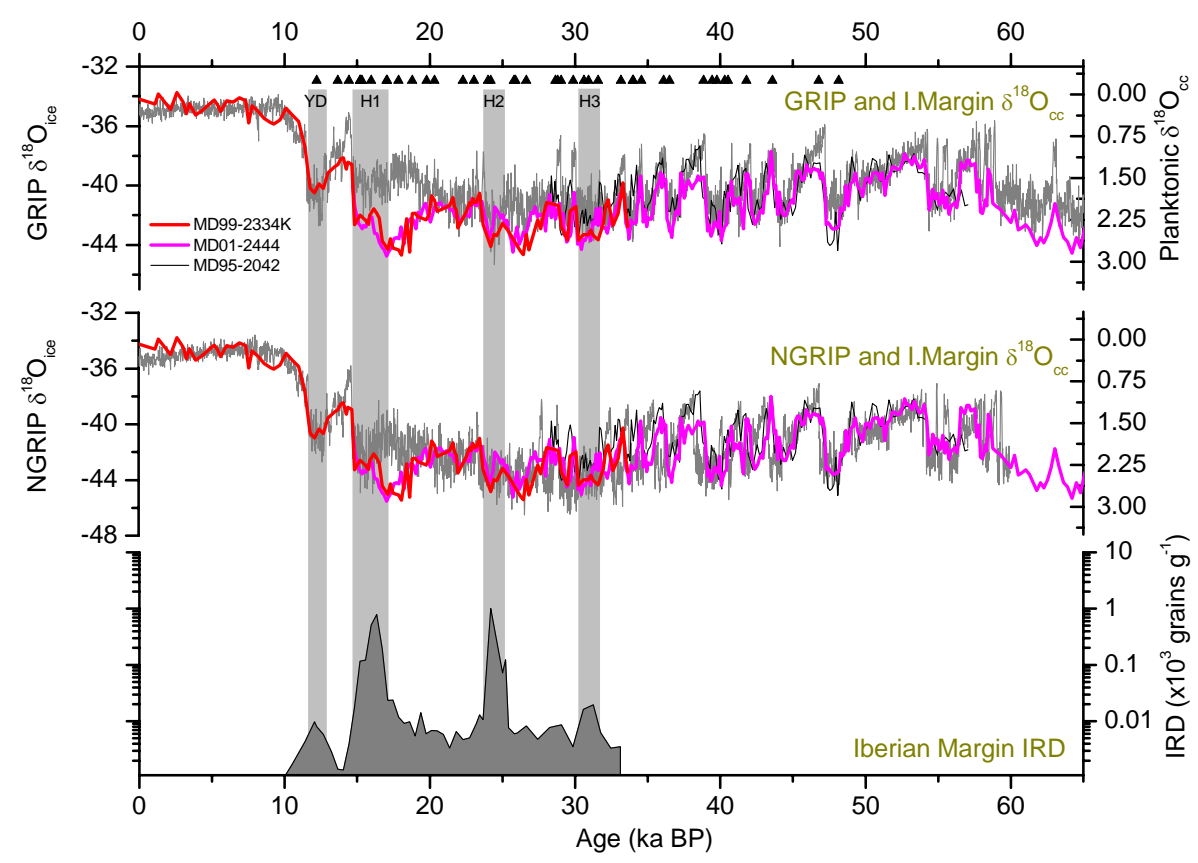

Fig. 1. Correlation between Greenland and planktonic $\delta^{18} \mathrm{O}$ from three Iberian Margin sediment cores. Black filled triangles indicate a selection of published radiocarbon dates performed on Iberian Margin planktonic foraminifera (Bard et al., 2004b; Shackleton et al., 2004; Skinner and Shackleton, 2004). Upper plot shows the GRIP ice-core and planktonic $\delta^{18} \mathrm{O}$, both on the SFCP04 age-scale. Middle plot shows the NGRIP ice-core on the GICC05 age-scale compared to planktonic $\delta^{18} \mathrm{O}$ on the SFCP04 age-scale. This illustrates the chronostratigraphic discrepancies between the age-scales. Lower plot shows spikes in ice-rafted debris abundance recorded in MD99-2334K from $\sim 33 \mathrm{ka}$ BP, also on the SFCP04 age-scale, indicating Heinrich-layer deposition (Skinner et al., 2003).

It is worth noting that much hinges on the fine-scale accuracy of the Greenland ice-core chronology. Importantly, this includes a determination of the precise timing of sealevel change relative to abrupt North Atlantic and Antarctic climate change (Chappell, 2002). On its own, this phase relationship sets important constraints on the mechanisms responsible for past abrupt climate change (Knutti et al., 2004). At present, the precise phasing of sea-level and abrupt climate change remains highly uncertain (Siddall et al., 2003; Skinner et al., 2007), partly because of a current paucity of sub-millennial resolution sea-level reconstructions, and partly because of the difficulty of obtaining a perfectly accurate ice-core chronology and " $\Delta$-age" (ice-age versus gasage) estimation technique.

With the aim of helping to set firm constraints on the timing of millennial events recorded in the Greenland ice-core, we revisit the "absolute calibration" of the GRIP age-scale recently proposed by Shackleton et al. (2004). This is carried out in the light of the new layer-counted GICC05 age-scale for the NGRIP ice-core (Svensson et al., 2008), and based on new radiometric dating of marine and speleothem archives (Hughen et al., 2006; Wang et al., 2006). The aim of this exercise is not to propose a "final" age-scale for the Greenland ice-cores (which would best be derived from glaciolog- ical constraints), but rather to illustrate the first order importance and utility of stratigraphy in assessing the accuracy of a given North Atlantic event chronology. After investigating the consistency of Greenland, North Atlantic, low-latitude speleothem and coral archives, it is concluded that biases (as opposed to random errors) may exist in both the marine radiocarbon dataset and the Greenland glaciological age-scale. This is despite the very great merits of the most recent developments of the Greenland ice-core chronology.

\section{Methods}

In a seminal paper, Shackleton et al. (2000) demonstrated a remarkably close coupling between surface-water temperature changes recorded on the Iberian Margin and stadial - interstadial temperature changes recorded in the Greenland icecores (Fig. 1). More recent studies have successfully replicated and confirmed this close stratigraphical link, which has allowed a variety of marine archives from the Iberian Margin to be securely tied to the Greenland chronostratigraphy (Vautravers and Shackleton, 2006; Martrat et al., 2007). For the most part, the correlation illustrated in Fig. 1 relies on near identical surface temperature signals; however Heinrich 
layers (ice-rafted debris) deposited on the Iberian Margin also provide robust markers for major Greenland stadial interstadial transitions. This is particularly important during Marine Isotope Stage (MIS) 2, where the similarity between Iberian Margin and Greenland temperature-proxy signals degrades (Skinner et al., 2003). Thus one constraint on stratigraphic correlation is that the Iberian Margin record cannot "slip" relative to Greenland in a way that significantly alters the inferred timing of Heinrich events with respect to Greenland stadial - interstadial transitions. In this respect, the placement of Heinrich events 2 and 3 just prior to Greenland Interstadials (GIS) 2 and 4 appears to be a robust set of tie-points. An alternative correlation that would for example place Heinrich 3 well before or just after GIS 4 (see middle panel of Fig. 1) would represent a marked departure from the pattern indicated by other Heinrich events/stadials, which generally occur just before major Greenland stadial - interstadial transitions. Support for this canonical view is provided by assessments of the relative timing of the most pronounced Antarctic millennial warm (AIM) events (EPICA community members, 2006), as well as the phasing of major precipitation anomalies recorded in low-latitude speleothem deposits (Wang et al., 2001, 2004, 2006).

One opportunity that arises from the alignment of Iberian Margin and Greenland records, which has long been recognised and exploited by Edouard Bard and colleagues, is that of being able to place marine radiocarbon dates from Iberian Margin sediment cores onto an independent glaciological age-scale. Seen from one angle, this may provide a useful radiocarbon calibration tool (Bard et al., 2004a). Seen from another angle, it may simply provide a crosscheck for a given Greenland/Iberian Margin stratigraphical alignment (Skinner and Shackleton, 2004). Going further still, it may be used to transfer radiometric dates from marine cores (or indeed speleothems) to the Greenland stratigraphy, thus effectively "calibrating" the Greenland age-scale. This approach was used by Shackleton et al. (2004) to propose the "absolutely calibrated" SFCP04-GRIP age-scale for Greenland (hereafter referred to as SFCP04). Perhaps most significantly, this calibration attempt served as a reminder that glaciological age-scales may not necessarily represent absolute calendar age-scales.

More recently, a new age-scale has been devised for the NGRIP Greenland ice-core based on careful layer counting and associated uncertainty estimates (Andersen et al., 2006; Svensson et al., 2008). This new age-scale (hereafter referred to as GICC05) has in effect superseded previous Greenland age-scales, and one of its great advantages is that it possesses clearly defined uncertainty estimates. However, the GICC05 age-scale differs from the apparently well-conceived SFCP04 age-scale by up to 1200 years. We are therefore in the possession of no fewer than 5 different Greenland age-scales, none of which are in complete agreement. If the GICC05 age-scale can be said to represent the current best estimate for the timing of the North At- lantic event stratigraphy, a clear explanation of its differences with regard to the "absolutely calibrated" SFCP04 age-scale seems necessary.

Figure 2 shows a compilation of planktonic radiocarbon dates performed in four Iberian Margin cores (Bard et al., 2004b; Shackleton et al., 2004; Skinner and Shackleton, 2004), expressed as deviations from modern atmospheric $\Delta{ }^{14} \mathrm{C}$. This way of presenting the radiocarbon dates accentuates the dynamic range of their deviations from stratigraphically assigned (ice-core) calendar ages. Two ice-core age-scales are adopted in Fig. 2: SFCP04 and GICC05. What this figure shows is that, when placed on the SFCP04 age-scale, Iberian Margin radiocarbon dates are in apparent agreement with available radiocarbon calibration datasets back to $\sim 35 \mathrm{ka} \mathrm{BP}$, including the coral datasets of both Bard et al. (1998) and Fairbanks et al. (2005), and the Cariaco Basin dataset of Hughen et al. (2006). The Cariaco dataset shown in Fig. 2 adopts the Hulu speleothem uranium-series age-scale, and is hereafter referred to as "Huliaco". It is noteworthy that the Huliaco chronostratigraphy reproduces a very similar history of atmospheric $\Delta^{14} \mathrm{C}$ change as predicted independently by paired U-Th/ ${ }^{14} \mathrm{C}$ dates performed on tropical corals. It is also noteworthy that the Iberian Margin reproduces a similar history of atmospheric $\Delta^{14} \mathrm{C}$ change when placed on the SFCP04 Greenland age-scale (most importantly between $\sim 20$ and $32 \mathrm{kaBP}$ ). If ascribed younger calendar ages, the Iberian Margin and Cariaco $\Delta^{14} \mathrm{C}$ records would fall below the coral data (which are assumed here to be correct and representative of atmospheric $\Delta^{14} \mathrm{C}$ ), unless the reservoir ages in both settings were increased by a commensurate amount. Hence a ${ }^{14} \mathrm{C}$ date that is assigned a revised calendar age 1200 years younger will maintain its $\Delta{ }^{14} \mathrm{C}$ at appropriate levels if it is also assigned a revised reservoir age 1200 higher. Under the proviso that reservoir ages have remained close to $\sim 420$ years in the Cariaco Basin (Hughen et al., 2006), and $\sim 500$ years on the Iberian Margin (Shackleton et al., 2004), Fig. 2 would therefore suggest close agreement between the SFCP04 Greenland age-scale and radiometric dating of tropical corals, Hulu, Cariaco Basin and the Iberian Margin.

At first sight, the same is not true of the GICC05 age-scale. As shown in Fig. 2, Iberian Margin radiocarbon dates placed on the GICC05 Greenland age-scale (and corrected for a 500 year reservoir age) do not agree with Huliaco or tropical coral dates. The immediate implication that arises from Fig. 2 is that either the GICC05 age-scale is right and Iberian Margin reservoir ages should be more than doubled (to as much as 1700 years); or the GICC05 age-scale is "missing time", in particular between Greenland interstadials (GIS) 2 and 8. Below we discuss each of these possibilities in turn. 
Absolute calibration of Greenland revisited

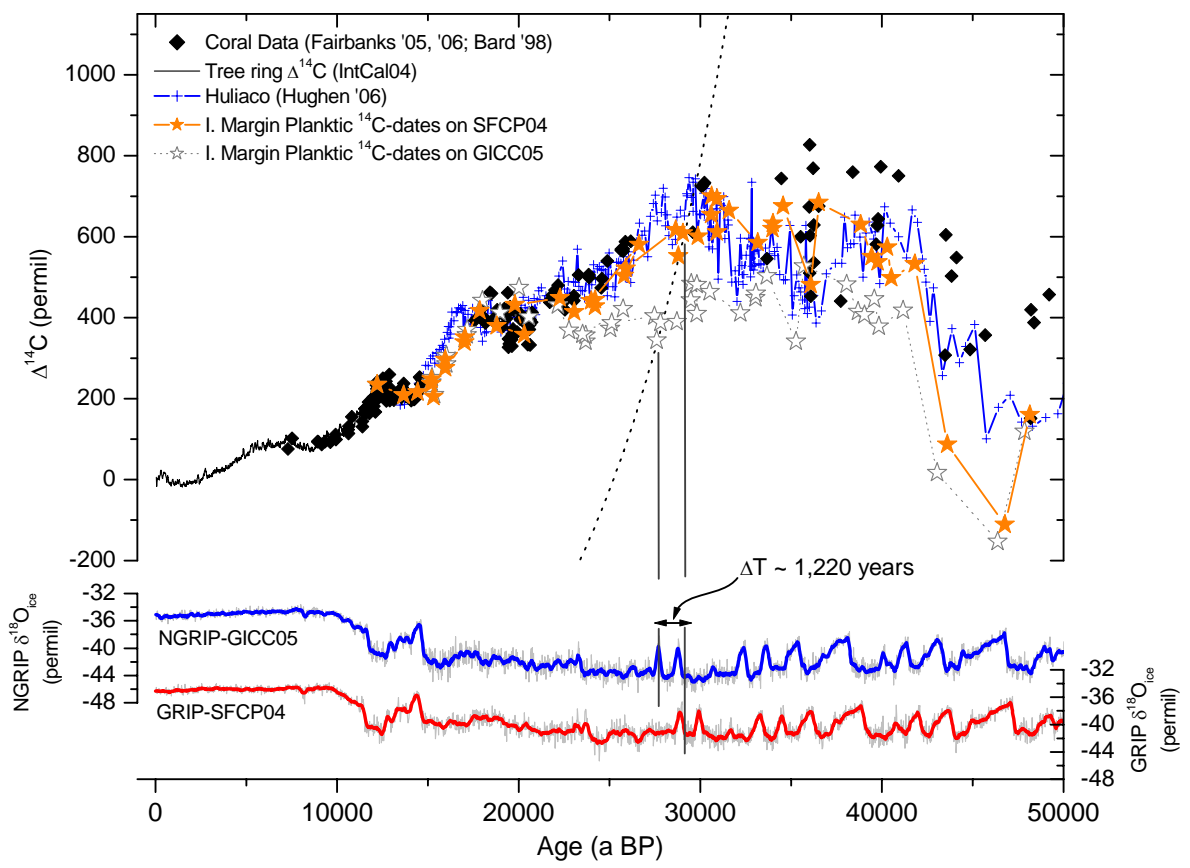

Fig. 2. Past atmospheric $\Delta^{14} \mathrm{C}$ variability as inferred from: the INTCAL tree-ring dataset (solid black line); paired radiocarbon and uraniumseries dating of tropical corals (Bard et al., 1998; Fairbanks et al., 2005) (filled diamonds); Cariaco planktonic radiocarbon dates placed on the Hulu chronology (Hughen et al., 2006) (crosses); Iberian Margin planktonic radiocarbon dates placed on the SFCP04 age-scale (filled stars); and Iberian Margin planktonic radiocarbon dates placed on the GICC05 age-scale (open stars). Lower panels show NGRIP on the GICC05 age-scale compared with GRIP on the SFCP04 age-scale (Svensson et al., 2008); vertical lines indicate the difference between SFCP04 and GICC05 for Greenland Interstadial (GIS) 3. The dotted curve is a decay line showing how altering the calendar age of GIS 3 affects $\Delta^{14} \mathrm{C}$ inferred from Iberian Margin radiocarbon dates.

\section{Discussion}

One way to assess Iberian Margin reservoir ages, relative to Cariaco basin reservoir ages, is to compare radiocarbon dates performed on correlative stratigraphical events from each region. This is illustrated in Fig. 3, where Cariaco Basin greyscale is shown correlated to Iberian Margin planktonic $\delta^{18} \mathrm{O}$; and offsets between the GICC05 and SFCP04 age-scales are compared with differences between correlative Iberian Margin and Cariaco radiocarbon dates. For this comparison, radiocarbon dates have been interpolated from the much higher resolution radiocarbon dataset. The reason for interpolating Cariaco dates in this way is to permit, as far as possible, a comparison of radiocarbon dates from precisely the same stratigraphic interval. A comparison of dates from a given "event", yet from different times within that event would not be sufficient. What emerges from Fig. 3 is that Iberian Margin reservoir ages are indeed likely to explain much of the discrepancy between the GICC05 and SFCP04 age-scales, as surmised by Svensson et al. (2008). Furthermore, Iberian Margin reservoir ages are likely to be larger than Cariaco Basin reservoir ages by $\sim 430$ years on average, prior to $\sim 22 \mathrm{ka}$ BP. Revising the Iberian Margin reservoir ages up- ward to $\sim 850$ years $(420+430$ years) prior to $22 \mathrm{ka} \mathrm{BP}$ goes some way in reconciling the GICC05 chronology with $\mathrm{Hu}-$ liaco, coral and speleothem dates. However, it does not go quite far enough: between $\sim 24$ and $38 \mathrm{ka} \mathrm{BP}$ the discrepancy between GICC05 and SFCP04 is significantly larger than the difference between Iberian Margin and Cariaco radicarbon dates. This statement must be true unless the grey line in the bottom panel of Fig. 3 can be said to be representative of the distribution of black crosses in the same figure. Increased Iberian Margin reservoir ages alone cannot therefore resolve the SFCP04/GICC05 age-scale discrepancy between $\sim 24$ and $38 \mathrm{ka} \mathrm{BP}$.

If instead Cariaco and Iberian Margin reservoir ages are both increased further, for example to 800 and 1230 years respectively (in order to completely reconcile Iberian Margin radiocarbon dates with both the GICC05 age-scale and tropical coral dates), then agreement between the Huliaco and coral datasets is destroyed. Therefore, if we accept the Hulu age-scale for Cariaco and the coral dates, then we cannot increase Cariaco and Iberian Margin reservoir ages much higher than $\sim 420$ and 850 years respectively. This would also suggest that GICC05 ages tend to be "too young", at least between GIS 2 and 8. 
Absolute calibration of Greenland revisited

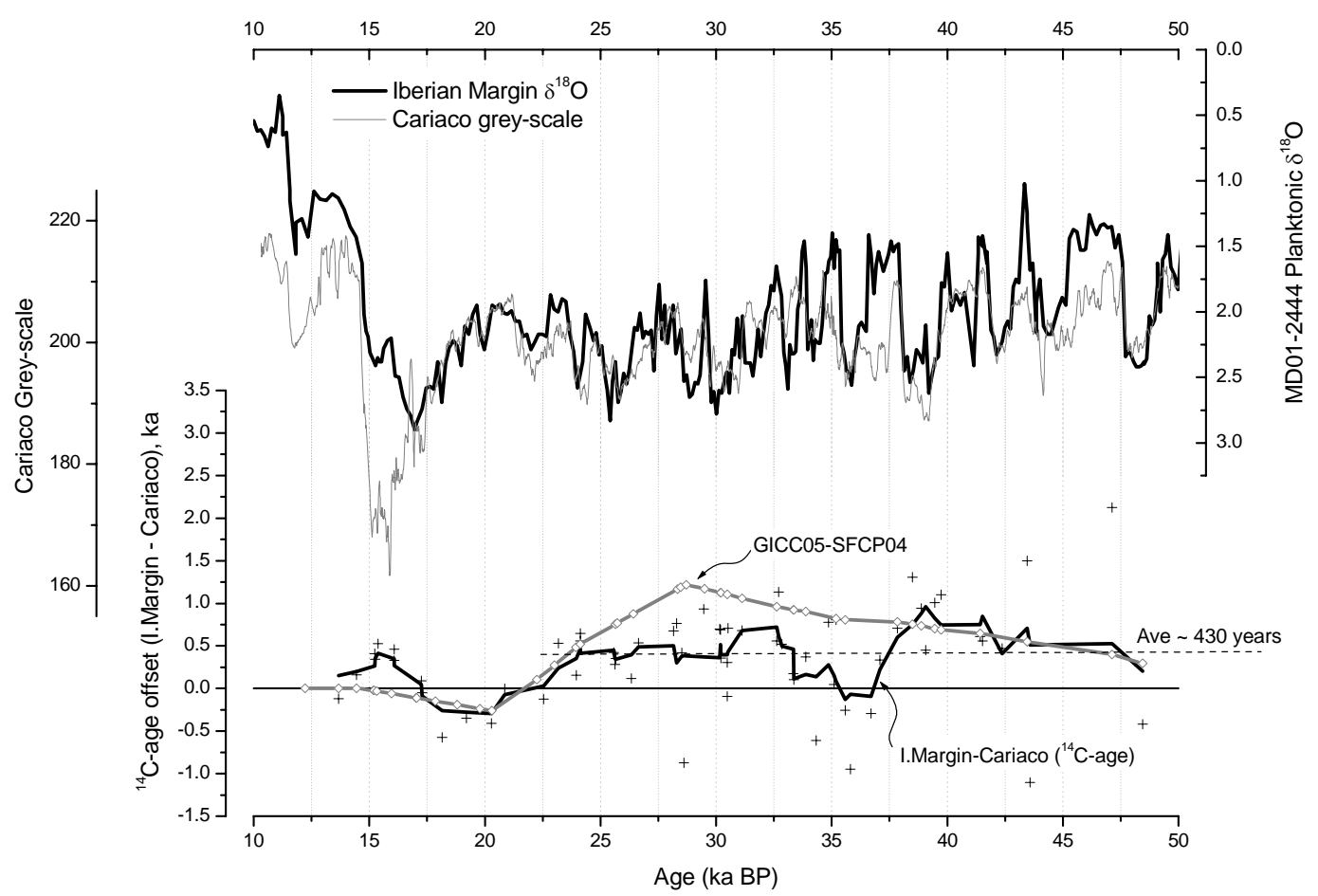

Fig. 3. Assessment of radiocarbon surface-water reservoir ages on the Iberian Margin, relative to the Cariaco Basin. Upper plot shows Cariaco grey-scale correlated with Iberian Margin planktonic $\delta^{18} \mathrm{O}$ from core MD01-2444 (Vautravers and Shackleton, 2006). Lower plot shows the offset between Iberian Margin radiocarbon dates and their Cariaco correlates (black crosses and 5-point running mean), and the offset between the GICC05 and SFCP04 ages-scales (grey line and open diamonds). Dashed horizontal line indicates the overall average radiocarbon age-offset prior to GIS 2 ( $\sim 430$ years). For Cariaco Basin reservoir ages $\sim 420$ years (Hughen et al., 2006), Iberian Margin reservoir ages should therefore approach $\sim 850$ years on average prior to GIS 2 .

In order to assess the "absolute" accuracy of GICC05 and SFCP04 further, a comparison can be made with ages drawn from uranium-series dated speleothem records. The comparison of speleothem records shown in Fig. 4 is used as an illustration of the reproducibility (and hence uncertainty) of the event stratigraphy and chronology in these archives. It is noteworthy that despite the greater accuracy of "absolute" dating in the speleothem records, they do not all exhibit the exact same stratigraphic signal, nor are they in complete agreement on the precise timing of individual event boundaries. Differences between speleothem event ages (i.e. their true uncertainty) can be as large as $\sim 1100$ years. This serves as a reminder that stratigraphic reproducibility ultimately constrains the true uncertainty limits of our records.

The correlations shown in Fig. 4 also allow the Iberian Margin radiocarbon compilation to be placed on an age-scale that is consistent with average Hulu and Boutavera uraniumseries ages inferred for Greenland event boundaries. Because Huliaco is broadly consistent with this age-scale no attempt has been made to alter it, with the exception of one small modification that has been made to bring it into better agreement with the high resolution Boutavera Cave record at $\sim 28 \mathrm{ka} \mathrm{BP}$. This results in slightly younger calendar ages than provided by Hughen et al. (2006) near $28 \mathrm{ka} \mathrm{BP}$.

Figure 5 now shows the Iberian Margin radiocarbon compilation placed on: 1) the GICC05 age-scale; and 2) the "speleothem age-scale" illustrated in Fig. 4. If our marine reservoir age estimates are accurate, and the GICC05 agescale is consistent with speleothem ages, all of the $\Delta^{14} \mathrm{C}$ time-series should overlap. While there is good agreement in Fig. 5 between the coral data, Huliaco and the Iberian Margin on a "speleothem age-scale" (thus tentatively confirming the reservoir age corrections proposed above), there remain significant discrepancies when the Iberian Margin is placed on the GICC05 age-scale. The GICC05 age-scale thus still appears to be slightly too young relative to speleothem ages (as observed relative to SFCP04 ages) between GIS 2 and GIS 6 in particular, even when higher reservoir ages are applied. The age offsets are not extremely large ( $\sim 800$ years at most), and notably are within the maximum counting error ascribed to the GICC05 age-scale (Svensson et al., 2008). Nevertheless, they are consistently positive rather than randomly 
Absolute calibration of Greenland revisited

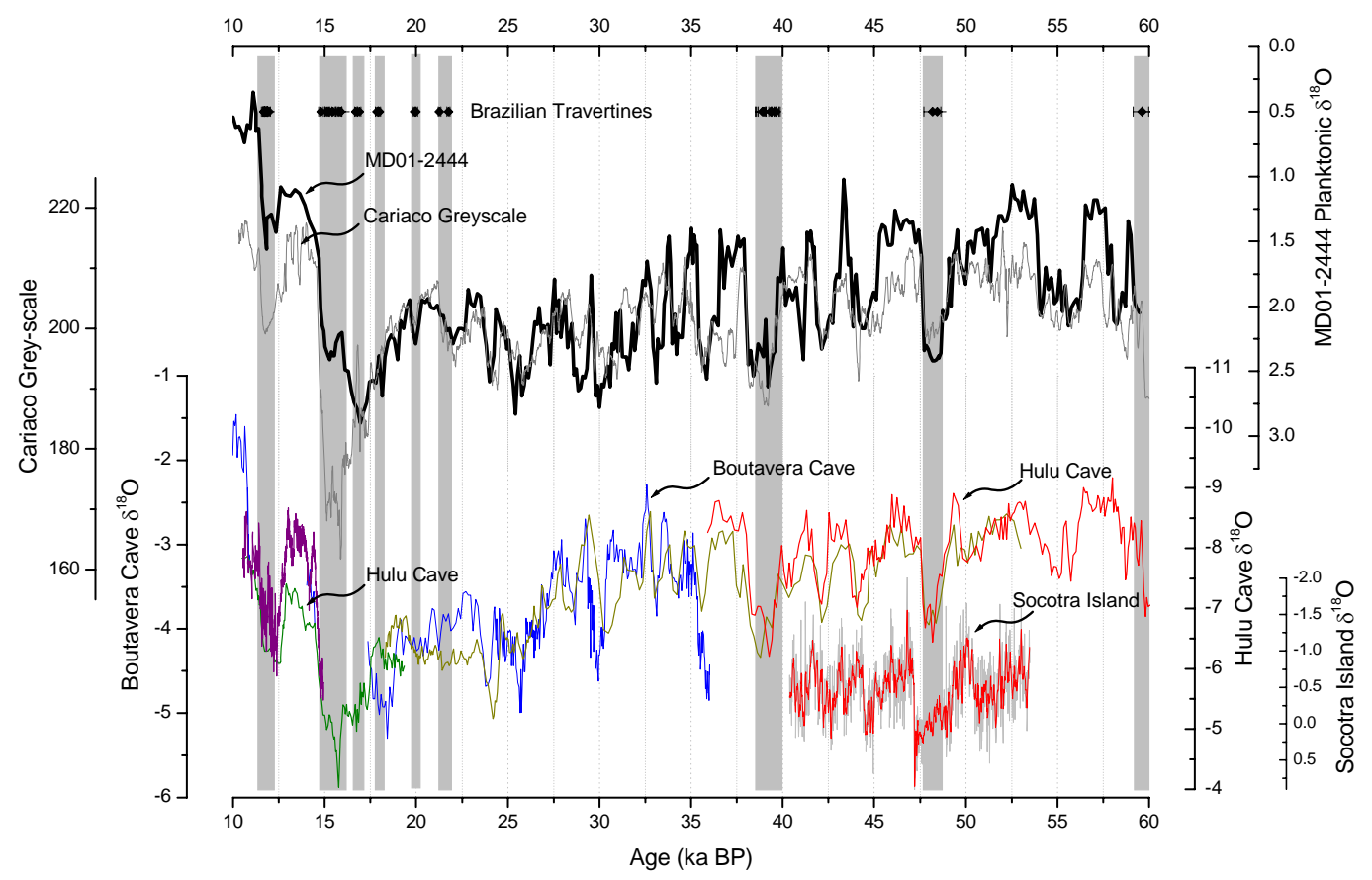

Fig. 4. Correlation of Iberian Margin planktonic $\delta^{18} \mathrm{O}$ from core MD01-2444 (Vautravers and Shackleton, 2006) with both the Hulu Cave and Boutavera Cave speleothem records (Wang et al., 2001, 2006). These records are shown compared with absolutely dated Brazilian travertine deposits (indicative of wet-periods coincident with North Atlantic stadials) (Wang et al., 2004), the Socotra Island speleothem record (Burns et al., 2003, 2004), and Cariaco grey-scale on the Hulu chronology (Hughen et al., 2006). The Cariaco age-scale has been slightly modified from (Hughen et al., 2006) near $28 \mathrm{ka} \mathrm{BP}$ to bring it into closer agreement with Boutavera, but is otherwise unchanged.

distributed about zero, which would tend to suggest a bias in the GICC05 age-scale towards younger ages. The nonrandom bias in age-offsets between GICC05 and speleothem records (with speleothem ages tending to be older) is also apparent in Fig. 4 and 6 of (Svensson et al., 2008). We might therefore conclude that while much of the original discrepancy between GICC05 and SFCP04 can indeed be attributed to larger than expected glacial reservoir ages on the Iberian Margin, some may still be attributable to missing years in the GICC05 age-scale. Arguably, this type of bias might be expected, especially during the height of the last glacial period, when accumulation rates over Greenland were low and annual layers are therefore difficult to discern (Andersen et al., 2006).

It is important to note that the method of chronostratigraphic integration outlined here has been used to suggest a slight bias in both marine radiocarbon ages on the Iberian Margin and in the GICC05 age-scale (in both cases between approximately 400 and 800 years). This specific conclusion is premised primarily on the accuracy of combined radiocarbon and uranium-series coral dating and of the speleothem chronostratigraphy, especially in the interval between GIS 1 and GIS 4, and especially in the Hulu Cave record (which tends to yield older ages for GIS 2-4). It also hinges on the proposed correlations between the Iberian Margin, Cariaco, Hulu and Greenland. Therefore, as the speleothem chronostratigraphy improves in future and as our correlations are reassessed, it may be possible (and necessary) to revise the explanation of the discrepancy between the GICC05 and SFCP04 age-scales proposed here. The method outlined in this paper indicates one way that this can be done. One obvious and important improvement in future will be the development of an adequate quantitative statistical analysis of the correlations and age discrepancies discussed here, in order to constrain more precisely the magnitude of possible (reservoir or ice-core) age biases.

\section{Conclusions}

The primary purpose of this investigation has been to illustrate a viable method of testing for chronostratigraphic convergence on an accurate Greenland calendar age-scale. In doing so, it has been suggested that a distinction can still be made between even the best glaciological ages and "absolute" ages. Thus, for example, it appears that the GICC05 age-scale cannot be made consistent with both 
Absolute calibration of Greenland revisited

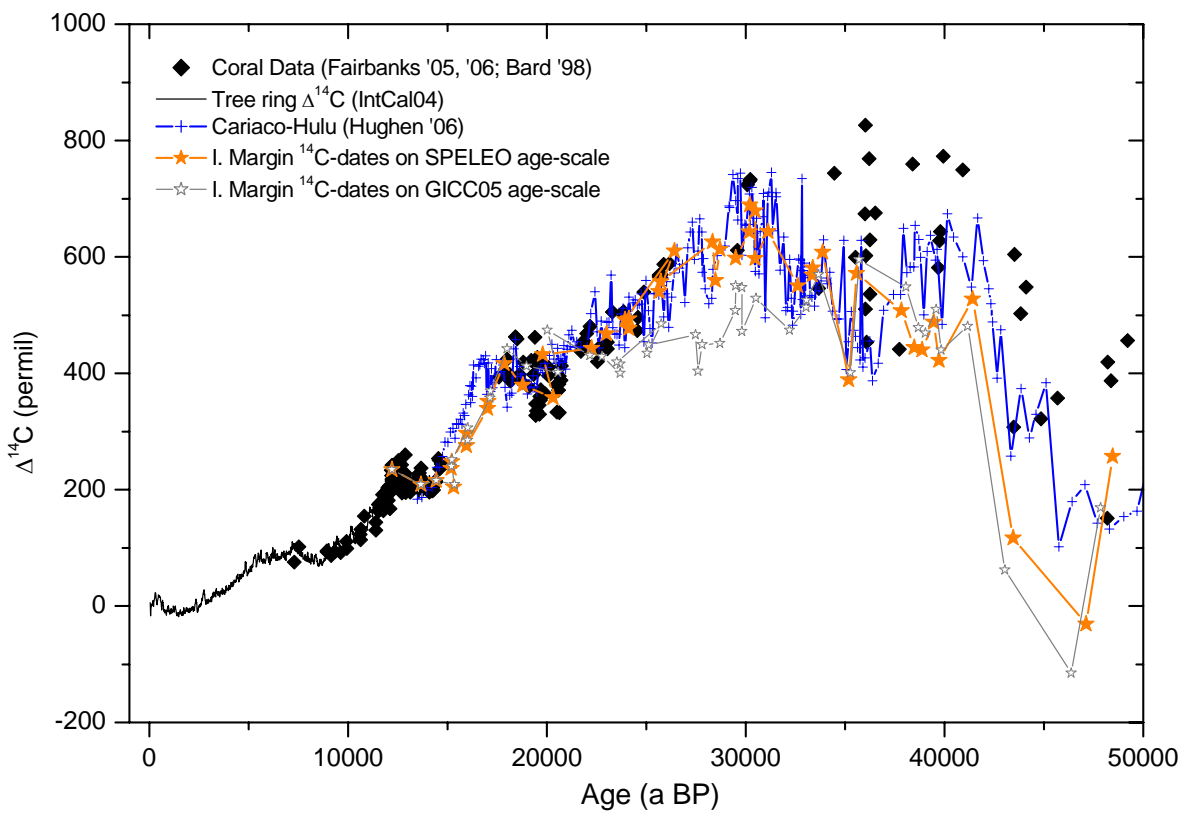

Fig. 5. Past atmospheric $\Delta^{14} \mathrm{C}$ variability as inferred from: the INTCAL tree-ring dataset (solid black line); paired radiocarbon and uraniumseries dating of tropical corals (Bard et al., 1998; Fairbanks et al., 2005) (filled diamonds); Cariaco planktonic radiocarbon dates placed on the slightly modified Hulu chronology shown in Fig. 4 (crosses); Iberian Margin planktonic radiocarbon dates placed on a speleothem age-scale (filled stars); and Iberian Margin planktonic radiocarbon dates placed on the GICC05 age-scale (open stars). Iberian Margin radiocarbon dates are corrected for a 500-year reservoir age after GIS 2, and for an 850-year reservoir age before GIS 2, as per Fig. 3.

Huliaco and paired ${ }^{14} \mathrm{C}-\mathrm{U} / \mathrm{Th}$ coral dates, even if increased marine reservoir ages are applied to the Cariaco radiocarbon dates. Iberian Margin radiocarbon dates tend to support this suggestion, which essentially hinges on an apparent bias in GICC05 ages (younger) relative to speleothem ages (older). If this specific conclusion proves to be incorrect, then it will be due to either: 1) biases in uranium-series ages for either Hulu or the corals (too old); or 2) biases in coral radiocarbon ages (too young). In both cases there are implications for inferred surface reservoir ages and changes in carbon cycling during the last glacial period. It is hoped that this type of analysis will in future contribute to the further improvement of the North Atlantic event chronostratigraphy (including glaciological age-scales), in particular as this bears on the timing of millennial climate events with respect to "absolutely-dated" sea level, palaeoceanographic or archaeological archives. The determination of the phasing of millennial sea-level fluctuations relative to North Atlantic climate events and Atlantic overturning circulation perturbations represents a case in point. The methodology presented here would suggest that paired radiocarbon and uraniumseries dating performed on corals amenable to sea-level reconstructions could eventually allow coral-based sea-level estimates, ice-cores and ocean circulation proxies to be successfully integrated.

Edited by: F. Peeters

\section{References}

Andersen, K. K., Svensson, A., Johnsen, S. J., Rasmussen, S. O., Bigler, M., Rothlisberger, R., Ruth, U., Siggaard-Andersen, M.-L., Steffensen, J. P., Dahl-Jensen, D., Vinther, B. M., and Clausen, H. B.: The Greenland Ice Core Chronology 2005, 1542 ka. Part 1: constructing the time scale, Quaternary Sci. Rev., 25, 3246-3257, 2006.

Bard, E., Arnold, M., Hamelin, B., Tisnerat-Laborde, N., and Cabioche, G.: Radiocarbon calibration by means of mass spectrometric $230 \mathrm{Th} / 234 \mathrm{U}$ and $14 \mathrm{C}$ ages of corals: An updated database including samples from Barbados, Mururoa and Tahiti, Radiocarbon, 40, 1085-1092, 1998.

Bard, E., Menot-Combes, G., and Rostek, F.: Present status of radiocarbon calibration and comparison records based on Polynesian corals and Iberian Margin sediments, Radiocarbon 46, 1189-1202, 2004a.

Bard, E., Rostek, F., and Menot-Combes, G.: Radiocarbon calibration beyond $2000014 \mathrm{C}$ yr B.P. by means of planktonic foraminifera of the Iberian Margin, Quaternary Res., 61, 204 214, 2004b.

Burns, S. J., Fleitmann, D., Matter, A., Kramers, J., and Al-Subbary, A. A.: Indian Ocean climate and absolute chronology over Dansgaard/eschger events 9 to 13, Science, 301, 1365-1368, 2003.

Burns, S. J., Fleitmann, D., Matter, A., Kramers, J., and Al-Subbary, A. A.: Corrections and Clarifications - Indian ocean climate and an absolute chronology over Dansgaard-Oeschger events 9 to 13, Science, 305, 1567, 2004. 
Chappell, J.: Sea level changes forced ice breakouts in the Last Glacial cycle: new results from coral terraces, Quaternary Sci. Rev., 21, 1229-1240, 2002.

EPICA community members: One-to-one coupling of glacial variability in Greenland and Antarctica, Nature, 444, 195-198, 2006.

Fairbanks, R. G., Mortlock, R. A., Chiu, T.-C., Cao, L., Kaplan, A., Guilderson, T., Fairbanks, T. W., Bloom, A. L., Grootes, P. M., and Nadeau, M.-J.: Radiocarbon calibration curve spanning 0-50000 years BP based on paired 230Th/234U/238U and 14C dates on pristine corals, Quaternary Sci. Rev., 24, 1781-1796, 2005.

Hughen, K., Southon, J., Lehman, S., Bertrand, C., and Turnbull, J.: Cariaco Basin $14 \mathrm{C}$ calibration and activity record over the past 50000 years updated from the Cariaco Basin, Quaternary Sci. Rev., 25, 3216-3227, 2006.

Knutti, R., Fluckiger, J., Stocker, T. F., and Timmerman, A.: Strong interhemispheric coupling of glacial climate through freshwater discharge and ocean circulation, Nature, 430, 851-856, 2004.

Martrat, B., Grimalt, J. O., Shackleton, N. J., de Abreu, L., Hutterli, M. A., and Stocker, T. F.: Four climatic cycles of recurring deep and surface water destabilizations on the Iberian Margin, Science, 317, 502-507, 2007.

Shackleton, N. J., Fairbanks, R. G., Chiu, T.-C., and Parrenin, F.: Absolute calibration of the Greenland time scale: implications for Antarctic time scales and for D14C, Quaternary Sci. Rev., 23, 1513-1522, 2004.

Shackleton, N. J., Hall, M. A., and Vincent, E.: Phase relationships between millennial-scale events 64000-24000 years ago, Paleoceanography, 15, 565-569, 2000.

Siddall, M., Rohling, E., Almogi-Labin, A., Hemleben, C., Meischner, D., Schmelzer, I., and Smeed, D. A.: Sea-level fluctuations during the last glacial cycle, Nature, 423, 853-858, 2003.
Skinner, L. C., Elderfield, H., and Hall, M.: Phasing of millennial events and Northeast Atlantic deep-water temperature change since $\sim 50 \mathrm{ka} \mathrm{BP}$, in: "Past and Future Changes of the Ocean's Meridional Overturning Circulation: Mechanisms and Impacts", edited by: Schmittner, A., Chiang, J., and Hemming, S. R., AGU Monograph, 197-208, 2007.

Skinner, L. C. and Shackleton, N. J.: Rapid transient changes in Northeast Atlantic deep-water ventilationage across Termination I., Paleoceanography, 19, 1-11, doi:10.1029/2003PA000983, 2004.

Skinner, L. C., Shackleton, N. J., and Elderfield, H.: Millennialscale variability of deep-water temperature and d18Odw in dicating deep-water source variations in the Northeast Atlantic, 0-34 cal. ka BP, Geochem. Geophy. Geosy., 4, 1-17, doi:10.1029/2003GC000585, 2003.

Svensson, A., Andersen, K. K., Bigler, M., Clausen, H. B., DahlJensen, D., Davies, S. M., Johnsen, S. J., Muscheler, R., Parrenin, F., Rasmussen, S. O., Röthlisberger, R., Seierstad, I., Steffensen, J. P., and Vinther, B. M.: A 60000 year Greenland stratigraphic ice core chronology, Clim. Past, 4, 47-57, 2008, http://www.clim-past.net/4/47/2008/.

Vautravers, M. and Shackleton, N. J.: Centennial scale surface hydrology off Portugal during Marine Isotope Stage 3: Insights from planktonic foraminiferal fauna variability, Paleoceanography, 21, 1-13, doi:10.1029/2005PA001144, 2006.

Wang, X., Auler, A. S., Edwards, R. L., Cheng, H., Cristalli, P. S., Smart, P. L., Richards, D. A., and Shen, C.-C.: Wet periods in northeastern Brazil over the past $210 \mathrm{kyr}$ linked to distant climate anomalies, Nature, 432, 740-743, 2004.

Wang, X., Auler, A. S., Edwards, R. L., Cheng, H., Ito, E., and Solheid, M.: Interhemispheric anti-phasing of rainfall during the last glacial period, Quaternary Sci. Rev., 25, 3391-3403, 2006.

Wang, Y. J., Cheng, H., Edwards, R. L., An, Z. S., Wu, J. Y., Shen, C.-C., and Dorale, J. A.: A high-resolution absolute-dated late Pleistocene monsoon record from Hulu Cave, China, Science, 294, 2345-2348, 2001. 